\title{
Effect of the $\mathrm{Al}_{2} \mathrm{O}_{3}$ Content in the Slag on the Chemical Reactions and Nonmetallic Inclusions during Electroslag Remelting
}

\author{
REINHOLD S.E. SCHNEIDER, MANUEL MOLNAR, GERALD KLÖSCH, \\ and CHRISTOPHER SCHÜLLER
}

\begin{abstract}
The service life of roller bearings is extremely sensitive to large and hard nonmetallic inclusions (NMIs), requesting the highest standards in their production. To determine the metallurgical possibilities, the effect of $\mathrm{Al}_{2} \mathrm{O}_{3}$ contents between 0 and 33 pct in the remelting slag was investigated by remelting a roller bearing steel in an experimental electroslag remelting (ESR) plant. Thereby, changes in the chemical composition of the materials (electrode $v s$ ingots) and in the remelting slag during remelting, as well as the amount and composition of the NMIs prior to and after remelting, were investigated. Changes in the chemical composition can largely be explained by equilibrium reactions between the slag and the metal, thereby low $\mathrm{Al}$ contents in the remelted materials could only be achieved with the lowest $\mathrm{Al}_{2} \mathrm{O}_{3}$ contents in the slag. Furthermore, higher $\mathrm{Al}_{2} \mathrm{O}_{3}$ contents in the slag also lead to higher oxygen and sulfur contents in the steel as well as higher amounts of NMIs after remelting. The composition of the NMIs changed from alumina type for high $\mathrm{Al}_{2} \mathrm{O}_{3}$ contents to spinel type and other mixed $\mathrm{MgO}-\mathrm{SiO}_{2}$ oxides for low $\mathrm{Al}_{2} \mathrm{O}_{3}$ contents. The results indicate solutions for the production of bearing steels with the lowest amounts of undesired large and hard NMIs.
\end{abstract}

https://doi.org/10.1007/s11663-020-01896-8

(C) The Author(s) 2020

\section{INTRODUCTION}

BEARING steels, which are exposed to extreme service environments, such as high contact pressure, high rotational speed, and elevated temperatures, suffer rolling contact fatigue (RCF). This RCF is a key factor affecting bearing life. Many authors ${ }^{[1-12]}$ describe that nonmetallic inclusions (NMI) besides other factors, e.g., hardness, brittleness, and possible residual stresses, have significant influence on fatigue properties. NMIs occur typically in low or extremely low volume fractions. ${ }^{[1,2,9]}$ Thereby, at low oxygen contents of $<10 \mathrm{ppm}$, the particle size distribution of oxide inclusions can differ significantly even if the oxygen content is the same. ${ }^{[9]}$ According to Reference 5, microcracks start

REINHOLD S.E. SCHNEIDER is with the University of Applied Sciences Upper Austria, Stelzhamerstrasse 23, Wels 4600, Austria. Contact email: reinhold.schneider@fh-wels.at. MANUEL MOLNAR is with the K1-MET GmbH, Stahlstraße 14, Linz 4020, Austria. GERALD KLÖSCH and CHRISTOPHER SCHÜLLER are with the voestalpine Stahl Donawitz GmbH, Kerpelystrasse 199, Leoben 8700, Austria.

Manuscript submitted December 30, 2019.

Article published online July 6, 2020. preferentially at complex oxisulfides rather than plain sulfides, but no simple relationships can be established. However, differences in the sulfur content have a strong effect on RCF. ${ }^{[1]}$ The NMI size distribution, orientation, and hot forming can contribute to obtaining more favorable conditions, ${ }^{[5,12]}$ but the published work on the effect of hot deformation is still sparse. ${ }^{[10]}$ The inclusion-matrix interface plays an important role in RCF life. ${ }^{[2,3,8,10,11]}$ Hot isostatic pressing has been found to be an effective method to increase RCF life by closing cavities between inclusions and the metal matrix. ${ }^{[8]}$ $\mathrm{SiO}_{2}-\mathrm{Al}_{2} \mathrm{O}_{3}$ inclusions are found to be less harmful than $\mathrm{Al}_{2} \mathrm{O}_{3}$ or $\mathrm{Al}_{2} \mathrm{O}_{3}-\mathrm{CaO}$ inclusions. ${ }^{[11]}$ The effect of NMIs on roller bearing fatigue can also be assessed by numerical methods; thereby, the maximum inclusion size is most relevant. ${ }^{[1-3,6,12]}$ The size of NMIs is also relevant for other subsurface crack initiation under fatigue loading conditions; therefore, smaller inclusions are associated with longer fatigue life. ${ }^{[7]}$

As a result, the production of high-purity bearing steels is one of the greatest challenges in steel metallurgy. Recent investigations on super clean bearing steels show that MnS-type inclusions are not particularly detrimental to the bearing component life, whereas oxides, such as $\mathrm{Al}_{2} \mathrm{O}_{3}$ and $\mathrm{TiN}$, as well as silicates, act as favorable 
sites for crack nucleation. ${ }^{[3]}$ Besides the NMI type, the varying elastic properties of the different NMIs affect the flow of forces within the material. A "stiff" inclusion (E-modulus NMI > E-modulus of the matrix) supports the matrix because it attracts the flow of force. This leads to a higher stress level not only inside the NMI but also inside the matrix zone, where the force flows into the NMI. This "high stressed" area is called the pole zone. At the pertinent equator, the matrix is relieved form load. Conversely, with a "soft" inclusion (E-Modulus NMI $<$ E-Modulus of the matrix), some of the forces pass by the NMI, and the matrix in terms of load is relieved at the pole zone, with more load being found at the equator area. Therefore, an important objective in terms of material optimization is to reduce the number and size of NMIs, which act as "internal notches," or to gain a positive effect on their distribution and to minimize their risk potential by changing their chemical composition. ${ }^{[4]}$ Furthermore, as described in Reference 3 , the crack propagation under RCF follows the prior austenite grain boundaries, which can also be affected by the electroslag remelting (ESR) process.

The ESR process is used to minimize inhomogeneities, such as segregations or shrink holes, and to improve the cleanliness level, in particular reducing the amount of larger NMIs. ${ }^{[13-19]}$ The remelting slag has a strong effect on the cleanliness level as well as on the composition of inclusions formed after remelting. ${ }^{[13,14,18-24]}$ Furthermore, the slag composition and its basicity have a significant effect on silicon losses. ${ }^{[13,14,19,23,25]}$

The effect of various remelting parameters on NMIs has found renewed interest in recent years due to rising demands on steel quality. The effect of a protective atmosphere and of slag deoxidation treatment on a corrosion-resistant die steel is documented in Reference 17, showing that both procedures can provide improvements for electrodes with high oxygen contents. Results from industrial trials on hot work tool steels and a martensitic $\mathrm{Cr}-\mathrm{Ni}$ steel demonstrate the excellent refining capabilities of, especially, protective gas ESR. ${ }^{[26,27]}$ The effect of higher $\mathrm{SiO}_{2}$ contents in the remelting slag on the formation of NMIs on a hot work tool steel is described in Reference 28, showing, in agreement with Reference 13, that larger mixed-type inclusions are formed at higher $\mathrm{SiO}_{2}$ contents. However, similar to Reference 26, $\mathrm{MgO} \cdot \mathrm{Al}_{2} \mathrm{O}_{3}$ (MA) spinels represent the majority of the NMIs, confirming the earlier results in References 13 and 23. The results in Reference 18 confirm this effect of high $\mathrm{SiO}_{2}$-containing slags. In contrast, the findings in Reference 19, with a similar steel grade but much higher oxygen content in the electrode, show no effect of the $\mathrm{SiO}_{2}$ content in the slag on the $\mathrm{SiO}_{2}$ content in the inclusions after remelting. However, the dominating types of inclusions were also MA spinels. Laboratory scale experiments on die steels in Reference 29 show advantages of low filling ratios (proportion of the electrode diameter to the mold diameter), a protective gas (argon), and a multicomponent slag compared to a plain $\mathrm{CaF}_{2}-\mathrm{Al}_{2} \mathrm{O}_{3}$ slag. Remelting with slags containing up to 10 pet $\mathrm{MgO}$ leads to a stronger reduction of larger NMIs, but the number of small inclusions $(<4 \mu \mathrm{m})$ increased. ${ }^{[24]}$ The effects of different slag compositions and a protective nitrogen atmosphere are documented in Reference 30 for the example of a hot-work tool steel. The main effect of protective gas was the elimination of the scaling at the electrode and related silicon losses. The strongest effect of the slag composition was found by a $\mathrm{CaO}$-free slag. The remelting of roller bearing steels was already widely investigated in the early years of ESR, ${ }^{[31]}$ showing significant advantages, especially in the amount of NMIs; however, the standard steelmaking praxis has improved greatly in the meantime, leading to excellent microstructures, reduced segregations, and low amounts of inclusions. ${ }^{[32]}$ Nevertheless, further improvements, especially regarding larger NMIs, seem feasible by ESR.

With this work, the effects of different $\mathrm{Al}_{2} \mathrm{O}_{3}$ contents, ranging from 0 to 33 pct during remelting with a protective nitrogen atmosphere, were investigated with a roller bearing steel, mainly focusing on changes in the chemical composition, especially silicon, aluminum, oxygen, and sulfur, and on the corresponding changes in type, content, size distribution, and composition of the NMIs.

\section{EXPERIMENTAL}

All experiments described in this article were performed on a laboratory scale in an ESR plant. Information on the plant configuration and typical operation procedures can be found in References 30 and 33.

The continuous cast and rolled bearing steel $100 \mathrm{Cr} 6$ (Material No. 1.3505, ASTM 52100) was used. The chemical composition of the steel was 1.04 wt pct C, 0.29 wt pet $\mathrm{Si}, 0.30$ wt pet $\mathrm{Mn}, 1.51$ wt pet $\mathrm{Cr}, 0.0012$ wt pet $\mathrm{Al}, 107 \mathrm{ppm} \mathrm{S}, 47 \mathrm{ppm} \mathrm{N}$, and 8 ppm O. All electrodes had a diameter of $70 \mathrm{~mm}$ and a bright machined surface. Four different slags with different $\mathrm{Al}_{2} \mathrm{O}_{3}$ contents ranging from 0 to $33 \mathrm{wt}$ pct were investigated in this experimental series. The first slag (33A) is a standard ESR slag containing roughly $1 / 3 \mathrm{CaF}_{2}, \mathrm{CaO}$, and $\mathrm{Al}_{2} \mathrm{O}_{3}$ each as well as smaller amounts of $\mathrm{SiO}_{2}$ and $\mathrm{MgO}$ (Table I). The other slags $(6,3$, and $0 \mathrm{~A})$ were also $\mathrm{CaF}_{2}-\mathrm{CaO}$ based and contained, among others, $\sim 7$ pct $\mathrm{SiO}_{2}, 4$ pet $\mathrm{MgO}$, and 6,3 , or 0 pct $\mathrm{Al}_{2} \mathrm{O}_{3}$.

All experiments were conducted with a frequency of $4.5 \mathrm{~Hz}$ in a mold with $125 \mathrm{~mm}$ diameter. The other operating parameters, thereof mainly the melting current, were selected to realize similar melt rates. The voltage is the result of the immersion depth $(0.5$ to $1 \mathrm{~cm})$ and the electrical conductivity of the slag (Table II). All remelting trials were performed using a controlled nitrogen protective gas atmosphere and no additions of deoxidants were used. 
Table I. Nominal Chemical Composition of the Slags Used (Mass Percent)

\begin{tabular}{lcccc}
\hline Slag & $\mathrm{Al}_{2} \mathrm{O}_{3}$ & $\mathrm{SiO}_{2}$ & $\mathrm{MgO}$ & Others \\
\hline $33 \mathrm{~A}$ & 33 & 2 & 3 & rest \\
$6 \mathrm{~A}$ & 6 & 7 & 4 & rest \\
$3 \mathrm{~A}$ & 3 & 7 & 4 & rest \\
$0 \mathrm{~A}$ & 0 & 7 & 4 & rest \\
\hline
\end{tabular}

Table II. Process Parameters of the Remelting Trials

\begin{tabular}{lcccc}
\hline Slag & $\begin{array}{c}\text { Slag } \\
(\mathrm{kg})\end{array}$ & $\begin{array}{c}\text { Current } \\
(\mathrm{kA})\end{array}$ & $\begin{array}{c}\text { Voltage } \\
(\mathrm{V})\end{array}$ & $\begin{array}{c}\text { Melt Rate } \\
(\mathrm{kg} / \mathrm{h})\end{array}$ \\
\hline $33 \mathrm{~A}$ & 2.0 & 2.4 & $\sim 62$ & 27 \\
$6 \mathrm{~A}$ & 2.6 & 3.4 & $\sim 62$ & 28 \\
$3 \mathrm{~A}$ & 2.6 & 3.5 & $\sim 57$ & 28 \\
$0 \mathrm{~A}$ & 2.6 & 3.6 & $\sim 59$ & 29 \\
\hline
\end{tabular}

After remelting, the ingots were forged to a final diameter of $40 \mathrm{~mm}$ and samples were taken from the upper third of the forged ingot for chemical analysis. Carbon, sulfur, oxygen, and nitrogen were analyzed by carrier gas hot extraction (LECO* CS 734 and LECO

*LECO is a trademark of LECO Corporation, St. Joseph, MI.

ON 736). All other elements were detected with optical emission spectroscopy (Thermo ARL 4460), and NMIs were detected by an automated scanning electron microscope-energy-dispersive spectrometer (SEM-EDS, Zeiss GeminiSEM, Oxford Instruments $\mathrm{X}-\mathrm{Max}$ ). Additionally, the top slag was analyzed with XRF spectroscopy (Panalytical CubiX) and pyrohydrolysis for fluorine (Thermofischer AQF-2100H) after remelting. Automated SEM-EDS scans were conducted in standardized fields of $150 \mathrm{~mm}^{2}$ to analyze the size and composition of NMIs. All detected NMIs with an oxygen content of $\geq 5$ wt pet and an S:O ratio of $<0.15$ were considered oxides. Inclusions containing more than $2 \mathrm{wt}$ pct oxygen and $1 \mathrm{wt}$ pct sulfur and an S:O ratio between 0.15 and 6.67 were categorized as oxisulfides (these are usually conglomerates of oxides and sulfides). NMIs with a sulfur content of $\geq 2 \mathrm{wt}$ pct and an O:S ratio of $<0.15$ were taken as sulfides.

\section{RESULTS}

\section{A. Chemical Composition of Ingots and Slags}

Changes in the chemical composition of the ingot can be taken from Figure 1.
Compared to the electrode, there is a slight reduction of the silicon content, which is more strongly pronounced at higher $\mathrm{Al}_{2} \mathrm{O}_{3}$ contents in the slag. In contrast, aluminum contents in the ingot were significantly higher after remelting, except for the slag $0 \mathrm{~A}$. Therefore, there is a strong correlation with the $\mathrm{Al}_{2} \mathrm{O}_{3}$ contents in the remelting slag. For both trace elements oxygen and sulfur, there is a trend of decreasing values in the remelted ingot with lower $\mathrm{Al}_{2} \mathrm{O}_{3}$ contents in the slag. In the case of sulfur, a strong reduction took place; otherwise, an increase in the oxygen content was observed.

Changes in the chemical composition of the slag except for $\mathrm{SiO}_{2}$ were rather minor (Figure 2). There was a slight increase in the $\mathrm{SiO}_{2}$ content, almost independent from the slag composition. The $\mathrm{Al}_{2} \mathrm{O}_{3}$ content remained also stable during remelting. The $\mathrm{FeO}$ content after remelting was at the detection limit $(0.01 \mathrm{pct})$ for all slags with low $\mathrm{Al}_{2} \mathrm{O}_{3}$ contents. Only for the slag with a high $\mathrm{Al}_{2} \mathrm{O}_{3}$ content was a significant $\mathrm{FeO}$ value observed. Additional investigations concerning the composition of the slag cover on the ingots revealed that the $\mathrm{SiO}_{2}$ content was about 2 pet lower than in the top slag.

\section{B. Nonmetallic Inclusions}

NMIs were evaluated regarding their amount (area fraction), type (oxides oxisulfides, sulfides, according to the criteria given previously), size (equivalent cycle diameter ECD), and type (chemical composition).

The content (in area percent) of all detected NMIs is shown in Figure 3. In the left chart, the content of NMIs is differentiated into two groups based on their size: into NMIs with an ECD larger than $5 \mu \mathrm{m}$ and into NMIs with an ECD from 1 to $5 \mu \mathrm{m}$. This total content is correlated with the summarized content of oxygen and sulfur (as almost all detected NMIs are related to oxides, sulfides, and their mixtures). There is a good correlation between these two amounts for all remelted ingots. In contrast, for the electrode, the amount of oxygen and sulfur (where the same check analysis is used for both positions) is relatively higher than the detected content of NMIs.

The right chart depicts the share of oxides, oxisulfides, and oxides in relation to the total content of NMIs; thereby, a strong increase in oxides and oxisulfides during remelting becomes visible. In reverse, pure sulfides disappear almost completely. In both charts, the amount of small and large, as well as of oxidic and oxisulfidic, NMIs is notably reduced with decreasing $\mathrm{Al}_{2} \mathrm{O}_{3}$ contents in the slag, reaching its lowest values at the $\mathrm{Al}_{2} \mathrm{O}_{3}$-free slag.

The charts in Figure 4 show the size distribution of oxides, oxisulfides, and sulfides and its collectivity. There are significantly smaller $(<5 \mu \mathrm{m}$ ECD for $\mathrm{Al}_{2} \mathrm{O}_{3}$-containing and $<2$ for the $\mathrm{Al}_{2} \mathrm{O}_{3}$-free slag) oxides after remelting than in the electrode. Also, the slope of the size distribution after remelting is even higher compared to the starting condition. As for the oxisulfides, a clear increase in the amount of NMI conglomerates can be found for all sizes after remelting with 


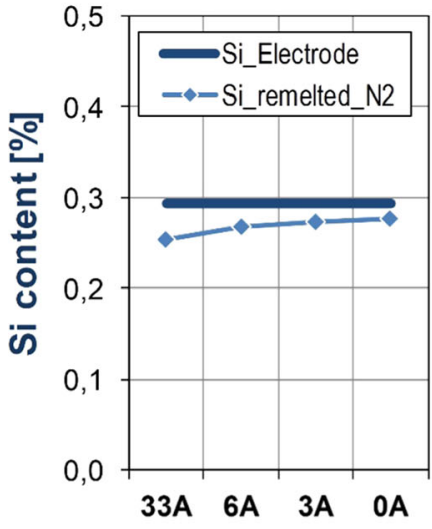

(a)

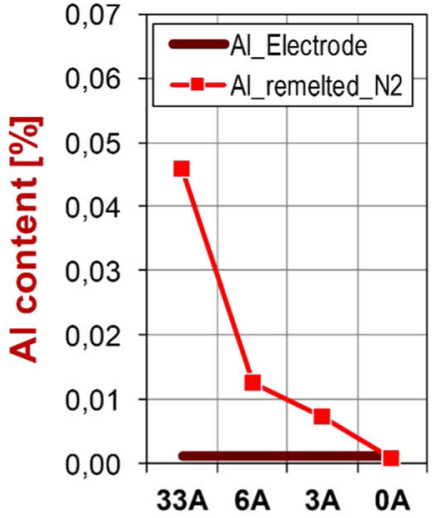

(b)

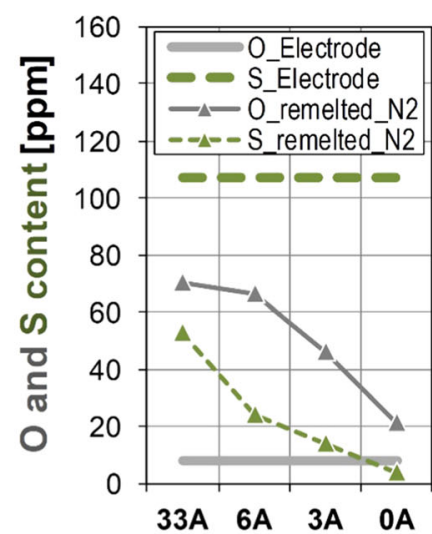

(c)

Fig. $1-$ Changes of the chemical composition of the steel during remelting with different $\mathrm{Al}_{2} \mathrm{O}_{3}$ contents in the slag: $(a)$ Si content, $(b) \mathrm{Al}$ content, and $(c) \mathrm{O}$ and $\mathrm{S}$ content.

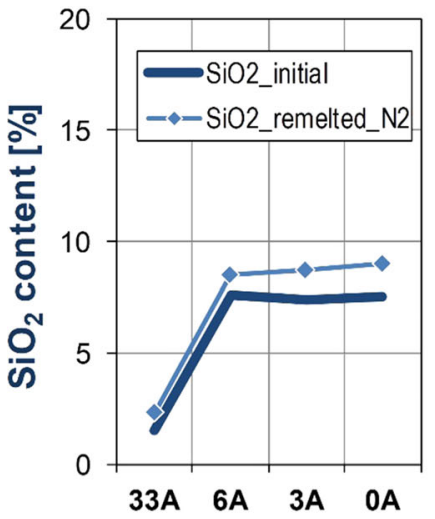

(a)

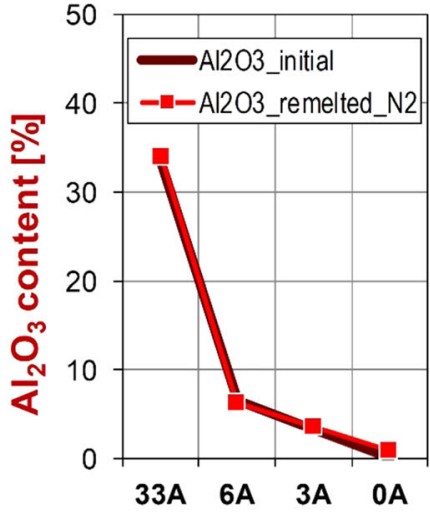

(b)

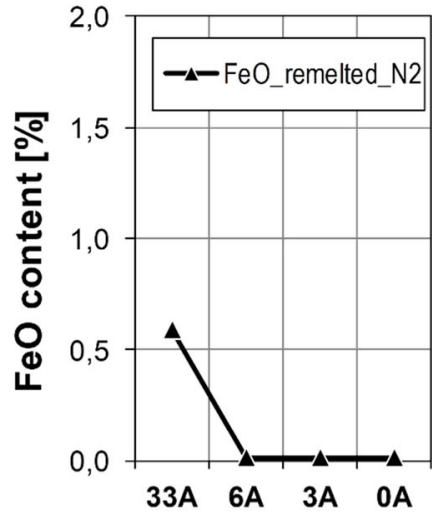

(c)

Fig. 2 - Changes of the chemical composition of the slag during remelting with different $\mathrm{Al}_{2} \mathrm{O}_{3}$ contents in the slag: $(a) \mathrm{SiO}_{2}$ content, $(b) \mathrm{Al}_{2} \mathrm{O}_{3}$ content, and (c) $\mathrm{FeO}$ content.

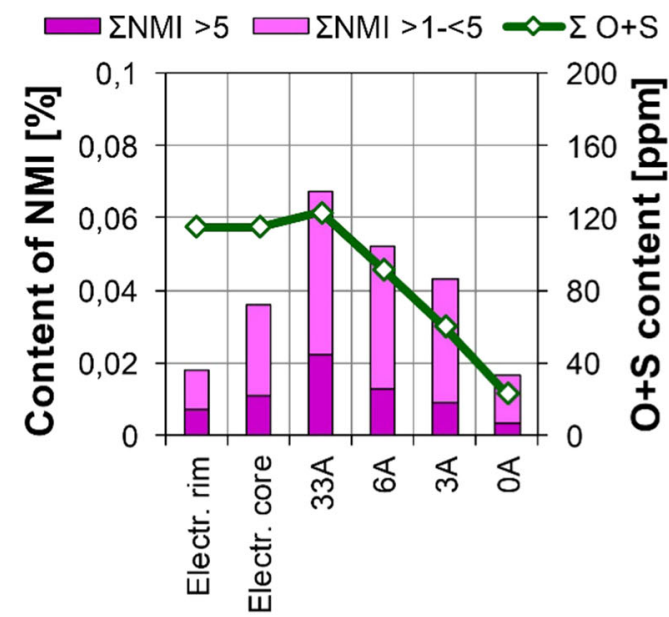

(a) $\square$ Sulfides $\square$ Oxisulfides $\square$ Oxides

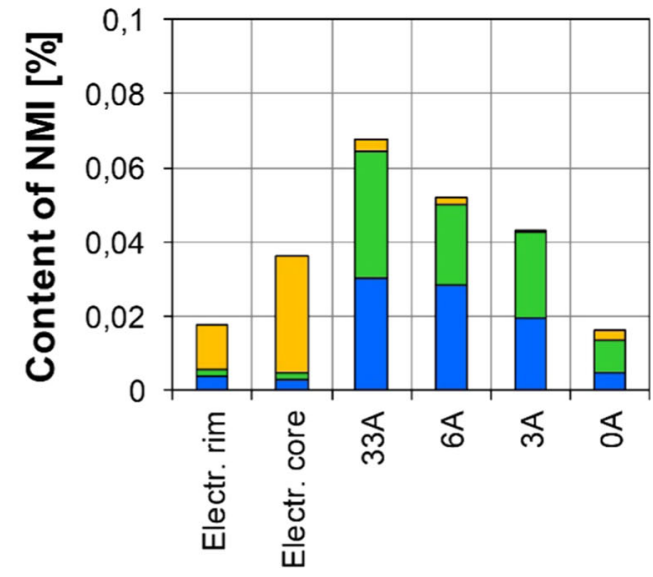

(b)

Fig. 3 - Content of NMIs in the electrode and in the ingots after remelting with different $\mathrm{Al}_{2} \mathrm{O}_{3}$ contents in the slag: $(a)$ differentiation by the size and correlation with the oxygen and sulfur content and $(b)$ differentiation by the NMI type. 


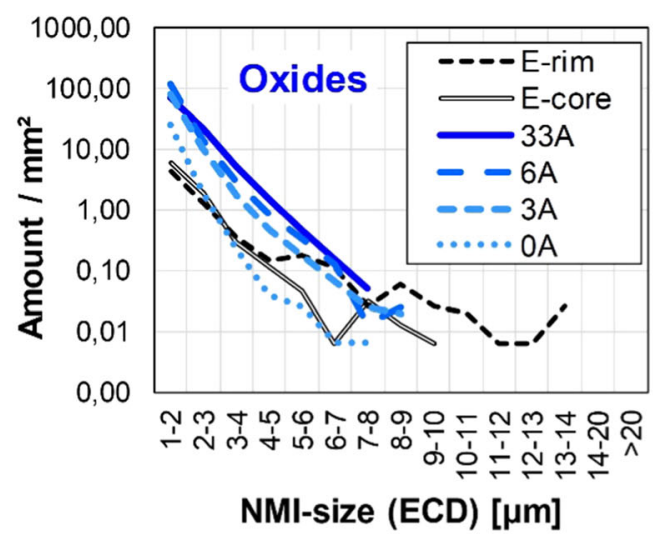

(a)

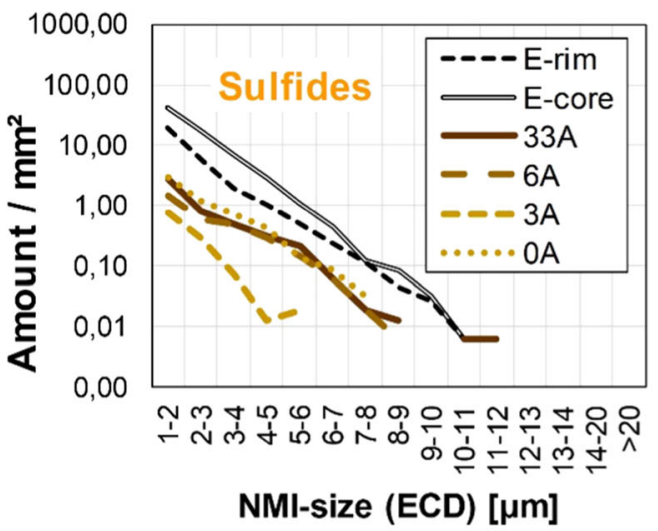

(c)

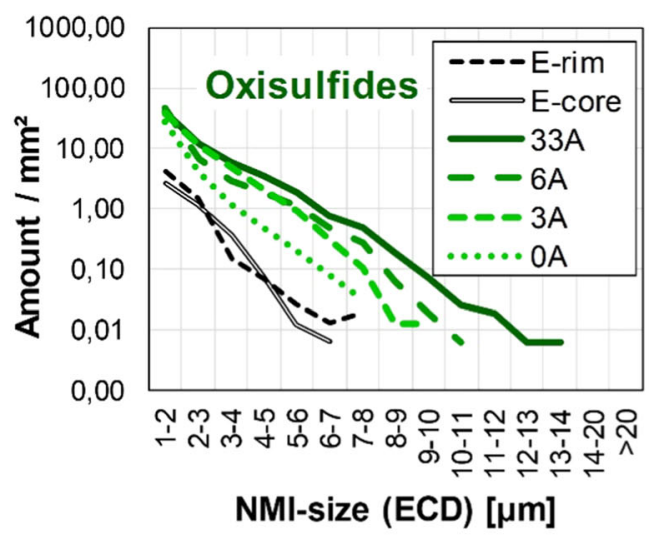

(b)

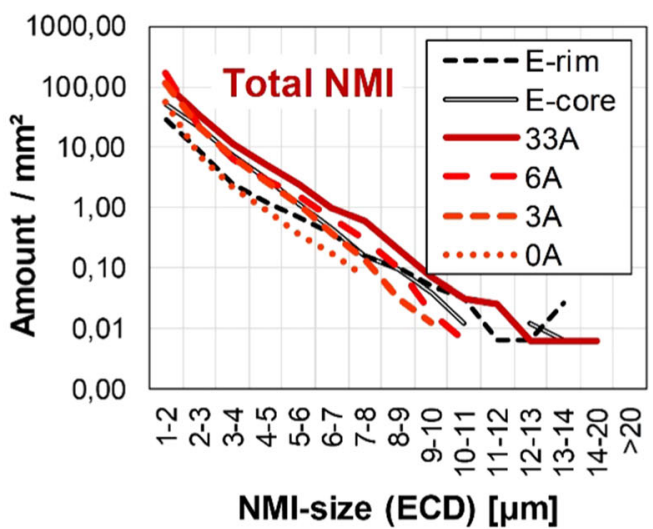

(d)

Fig. 4 - Size distribution of NMIs in the electrode and in the ingots after remelting with different $\mathrm{Al}_{2} \mathrm{O}_{3}$ contents in the slag: $(a)$ oxides, $(b)$ oxisulfides, $(c)$ sulfides, and $(d)$ total NMI.

$\mathrm{Al}_{2} \mathrm{O}_{3}$-containing slags. Thereby, remelting with the $\mathrm{Al}_{2} \mathrm{O}_{3}$-free slag leads to the lowest increase in the size distribution.

The number of pure sulfides is always reduced for almost all sizes (there are two larger inclusions after remelting with the 33 pct $\mathrm{Al}_{2} \mathrm{O}_{3}$-containing slag) during remelting. Thereby, the best result was achieved with 3 pct $\mathrm{Al}_{2} \mathrm{O}_{3}$ in the slag. The total amount of NMIs looks quite similar for all conditions, but the logarithmic scale has to be considered. Remelting with the highest $\mathrm{Al}_{2} \mathrm{O}_{3}$ content (33 pct), with a similar amount of NMIs above $10 \mu \mathrm{m}$ and significantly more NMIs below $10 \mu \mathrm{m}$, does not show any improvements compared to the electrode. Reducing the $\mathrm{Al}_{2} \mathrm{O}_{3}$ content ( 3 and 6 pct) results in a similar amount of NMIs as in the electrode, with a significant improvement for larger NMIs ( $>8$ to $9 \mu \mathrm{m}$ ), but significantly smaller $(<2 \mu \mathrm{m})$ NMIs. The lowest amount of NMIs, except for NMIs $<2 \mu \mathrm{m}$, was achieved after remelting with the $\mathrm{Al}_{2} \mathrm{O}_{3}$-free slag.

To illustrate the changes in the chemical compositions of the NMIs, the ternary system $\mathrm{Al}_{2} \mathrm{O}_{3}-\mathrm{MgO}-\mathrm{SiO}_{2}$, to which most of the oxides and the oxides within the oxisulfidic NMIs could be assigned, was used (Figures 5 and 6). The two positions of the electrode show a majority of mullite-type (highly $\mathrm{Al}_{2} \mathrm{O}_{3}-\mathrm{SiO}_{2}$ containing) NMIs with low amounts of $\mathrm{MgO}$. This type was significantly more sharply pronounced in the center region of the electrode. In the rim, additionally, a mixed $\mathrm{MgO}-\mathrm{SiO}_{2}$ type (forsterite) was found.

Remelting with the high alumina-containing slag leads to a complete change of the oxide inclusions toward an almost pure $\mathrm{Al}_{2} \mathrm{O}_{3}$ type. Lower alumina contents in the remelting slag resulted in MA spinel-type inclusions; thereby, the average composition shifted to lower $\mathrm{Al}_{2} \mathrm{O}_{3}$ contents in the NMIs when the alumina concentration in the slag was reduced. In contrast, the type of NMIs changed to $\mathrm{MgO}$ inclusions with various amounts of $\mathrm{SiO}_{2}$ when the alumina-free slag was used.

The sulfide inclusions were always of $\mathrm{MnS}$, independent from the remelting slag. In slags containing alumina, significant amounts of conglomerates (oxisulfides) consisting of various proportions of $\mathrm{Al}_{2} \mathrm{O}_{3}$ and $\mathrm{MnS}$ were also found. 


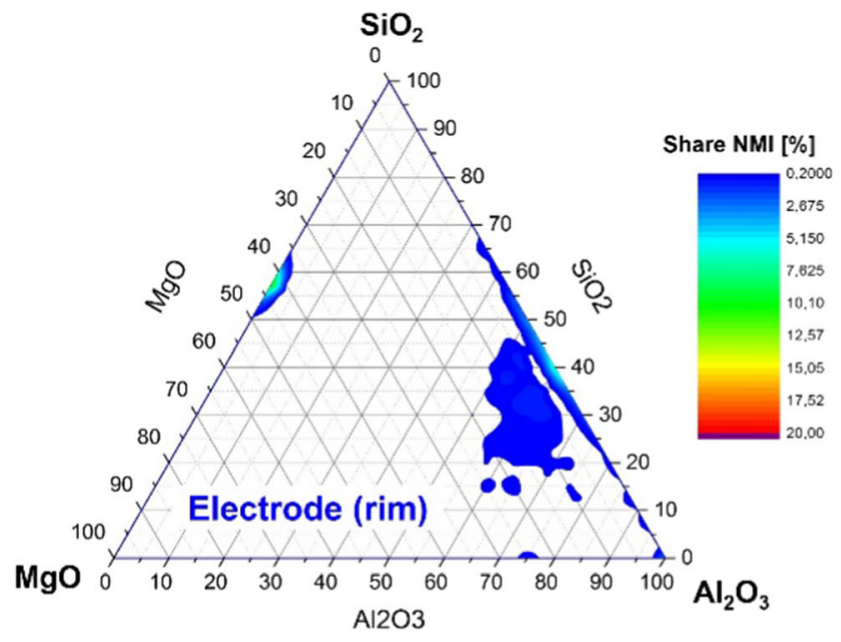

(a)

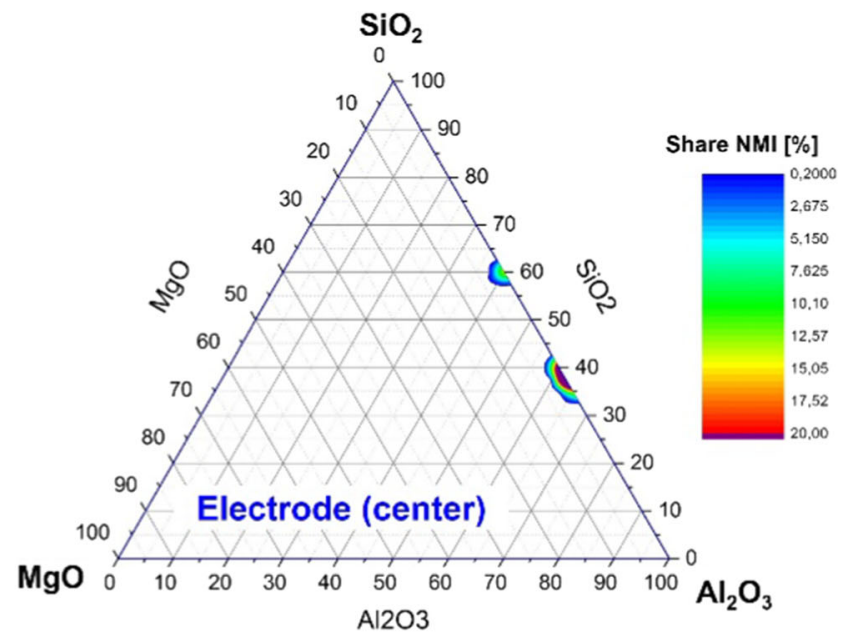

(b)

Fig. 5- Chemical composition of the NMIs in the electrode in the ternary system $\mathrm{Al}_{2} \mathrm{O}_{3}-\mathrm{MgO}_{-} \mathrm{SiO}_{2}:(a)$ rim and $(b)$ center.

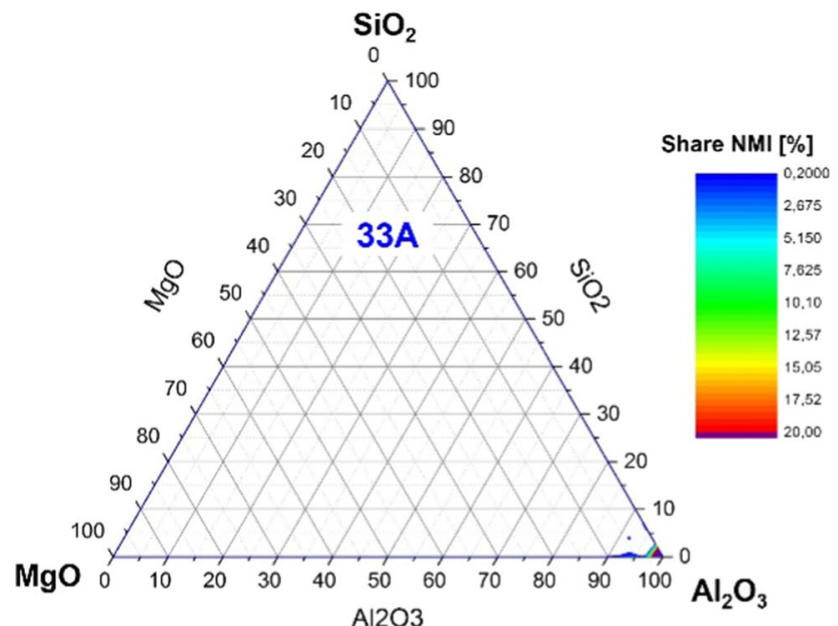

(a)

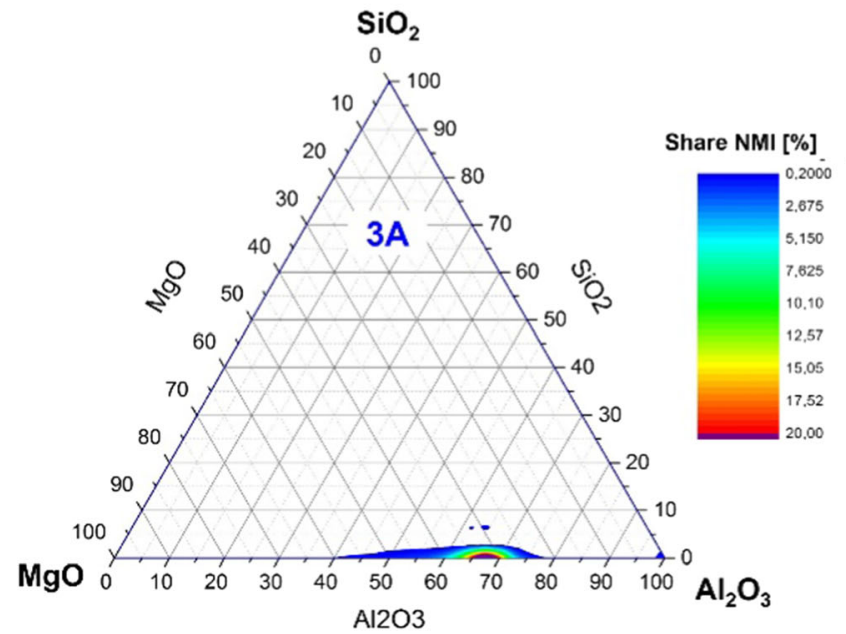

(c)

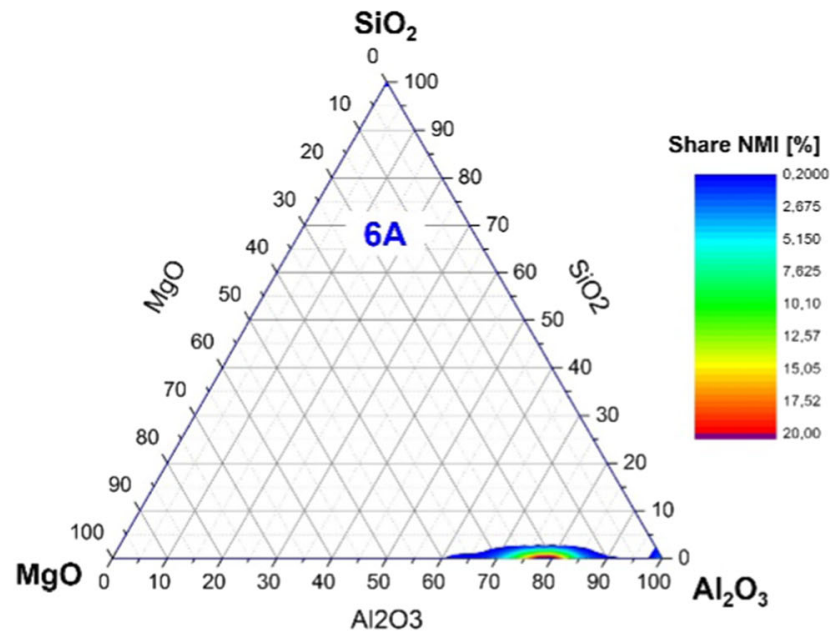

(b)

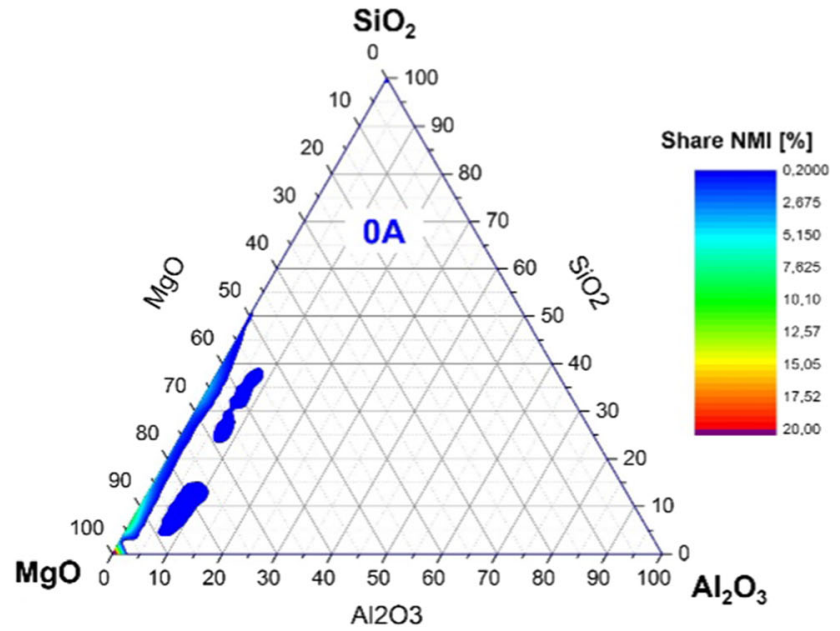

(d)

Fig. 6-Chemical composition of NMIs in the ingots after remelting with different $\mathrm{Al}_{2} \mathrm{O}_{3}$ contents in the slag in the ternary system $\mathrm{Al}_{2} \mathrm{O}_{3}-\mathrm{MgO}-\mathrm{SiO}_{2}$ : (a) slag $33 \mathrm{~A},(b)$ slag $6 \mathrm{~A},(c)$ slag $3 \mathrm{~A}$, and $(d)$ slag $0 \mathrm{~A}$. 


\section{DISCUSSION}

\section{A. Chemical Reactions}

The values of the $\mathrm{Si}$ and $\mathrm{Al}$ contents of the remelted ingots in comparison to the electrodes show, in agreement with References 13, 14, 18, 22 through 24, 30, and 34, a general correlation according to Eq. [1]. Thereby, higher aluminum contents correspond with lower silicon contents at rising alumina fractions in the slag.

$$
\begin{array}{r}
3[\mathrm{Si}]+2\left(\mathrm{Al}_{2} \mathrm{O}_{3}\right) \leftrightarrow 3\left(\mathrm{SiO}_{2}\right)+4[\mathrm{Al}] \\
\Delta G^{\circ}=-658,300+107.2 \mathrm{~T}(\mathrm{~J} / \mathrm{mol})^{[35]}
\end{array}
$$

However, the high $\mathrm{SiO}_{2}$ values cannot be explained completely by this relationship. Thereby, it has be taken into consideration that some enrichment of $\mathrm{SiO}_{2}$ in the top slag results from reduced $\mathrm{SiO}_{2}$ contents in the solidified slag cover at the ingot. A significant oxidation reaction with the atmosphere, as described for open remelting in References 17, 29, and 30, can be excluded, as a controlled protective nitrogen atmosphere was applied.

Both oxides $\mathrm{SiO}_{2}$ and $\mathrm{Al}_{2} \mathrm{O}_{3}$ can be assumed to stay in equilibrium with the melt according to Eqs. [2] and [3]:

$$
\begin{gathered}
{[\mathrm{Si}]+[\mathrm{O}] \leftrightarrow\left(\mathrm{SiO}_{2}\right)} \\
\Delta G^{\circ}=-581,900+221.8 T(\mathrm{~J} / \mathrm{mol})^{[35]} \\
2[\mathrm{Al}]+3[\mathrm{O}] \leftrightarrow\left(\mathrm{Al}_{2} \mathrm{O}_{3}\right) \\
\Delta G^{\circ}=-1,202,000+386.3 \mathrm{~T}(\mathrm{~J} / \mathrm{mol})^{[35]} \\
\Delta G^{\circ}=-1,205,115+386.714 \mathrm{~T}(\mathrm{~J} / \mathrm{mol})^{[36]}
\end{gathered}
$$

Equation [3] can also be regarded as the core reason for the increasing aluminum and oxygen contents in the ingot after remelting with alumina-containing slags. These higher oxygen contents contribute also to the oxidation of iron and the increase of $\mathrm{FeO}$ in the slag.

Changes in the sulfur content show, in agreement with, e.g., References 13, 29, 30, and 37, significant desulfurization in all remelting trials according to Eq. [4].

$$
2[\mathrm{~S}]+2\left(\mathrm{O}^{2-}\right) \leftrightarrow 2[\mathrm{O}]+2\left(\mathrm{~S}^{2-}\right)
$$

However, there is a clear relationship between the sulfur content in the remelted ingot and the alumina fraction of the slag. Based on Reaction 3 and the corresponding higher oxygen contents in the steel with rising alumina fractions in the slag, the sulfur remains in the metal. Higher contents of $\mathrm{Al}_{2} \mathrm{O}_{3}$ also reduce the basicity and, therefore, lower the desulfurization capacity of the slag. Hence, the highest degree of desulfurization could be observed with the lowest $\mathrm{Al}_{2} \mathrm{O}_{3}$ content in the slag. This strong desulfurization, in return, according to Eq. [4], provides oxygen into the liquid metal, which, as the aluminum content is extremely low, to a large extent, reacts with silicon according to Eq. [2], forming $\mathrm{SiO}_{2}$. Thereby, the significant loss of $\mathrm{Si}$ and the increase of $\mathrm{SiO}_{2}$ after remelting, especially for the $\mathrm{Al}_{2} \mathrm{O}_{3}$-free slag, where Reaction 1 is negligible, can be explained.

\section{B. Nonmetallic Inclusions}

Except for the electrode, there is a good agreement between the amount of NMIs and the content of oxygen plus sulfur in the steel, which correlates well with the findings in References 18, 19, 28, and 38. When comparing the three types of NMIs (oxides, oxisulfides, and sulfides) in Figure 3 with the $\mathrm{O}$ and $\mathrm{S}$ contents in Figure 1, the correlation between oxygen and oxides ( + oxisulfides) is much better than between sulfur and (oxi)sulfides. A possible reason for this deviation could be that different volumes have been analyzed and the probability of detecting rare larger inclusion is obvious.

The size distribution of the NMIs shows two fundamental effects. The first is a general reduction of NMI size for all diameters at reduced alumina contents in the slag, which is mainly based on the corresponding reduction in oxygen and sulfur. The second is a tendency toward more small inclusions (especially below $2 \mu \mathrm{m}$ ) and less larger inclusions after remelting, which is in agreement with References 18, 19, 27, and 30.

The NMI of the mullite type is typical for roller bearing steels. ${ }^{[32]} \mathrm{Al}_{2} \mathrm{O}_{3}$ and MA spinel-type NMIs are typical after remelting with alumina-containing slags ${ }^{[18,19,23,26-30,39]}$ and can be explained by the increasing aluminum and oxygen contents in the steel as well as the significant $\mathrm{MgO}$ content in the remelting slag. However, these types of NMIs are undesired in this steel due to the negative effects on fatigue properties. ${ }^{[3,11,32]}$ Only when the oxygen and the aluminum content in the liquid bath are kept at low levels can the formation of $\mathrm{Al}_{2} \mathrm{O}_{3}$-containing NMIs be avoided. Similar to Reference 30, and in agreement with References 17 through 19, 21, and 22, the NMIs detected in this work are newly formed during solidification, becoming entrapped by the progressing solidification, and are not remainders from the electrode, as found in Reference 39.

\section{SUMMARY AND CONCLUSIONS}

Based on the results achieved in this research, the following conclusions can be drawn.

1. Based on the thermodynamic analysis of slag-metal reactions, the $\mathrm{Al}_{2} \mathrm{O}_{3}$ content of the remelting slag has a strong effect on the aluminum, oxygen, and sulfur contents in the steel after remelting. Thus, lower alumina contents lead to lower element concentrations in the ingots.

2. Corresponding with the changes in the chemical composition, the amount of NMIs after remelting decreases with a reduction of $\mathrm{Al}_{2} \mathrm{O}_{3}$ in the slag. Thereby, particularly large inclusions are removed, while the amount of small inclusions (especially $<2$ $\mu \mathrm{m})$ increases.

3. The composition and type of NMIs changes significantly during remelting. High alumina-containing 
slags lead to $\mathrm{Al}_{2} \mathrm{O}_{3}$-type inclusions, low alumina-containing slags result in MA spinel-type inclusions, and remelting with alumina-free slags produces dominantly high $\mathrm{MgO}$ inclusions. Sulfides (essentially $\mathrm{MnS}$ type) are removed almost completely.

4. Only remelting with $\mathrm{Al}_{2} \mathrm{O}_{3}$-free $\mathrm{SiO}_{2}$-containing slags permits the production of clean roller bearing steels with the lowest amounts of hard and large NMIs.

\section{ACKNOWLEDGMENTS}

Open access funding provided by University of Applied Sciences Upper Austria. The authors gratefully acknowledge the funding support of the K1-MET $\mathrm{GmbH}$ metallurgical competence center. The research programme of the K1-MET competence center is supported by the Competence Center for Excellent Technologies (COMET), the Austrian programme for competence centers. COMET is funded by the Federal Ministry for Climate Action, Environment, Energy, Mobility, Innovation, and Technology; the Federal Ministry for Digital and Economic Affairs; the Federal States of Upper Austria, Tyrol, and Styria; as well as the Styrian Business Promotion Agency (SFG). Besides the public funding from COMET, this research project is partially financed by scientific partners and the industrial partner voestalpine Stahl Donawitz $\mathrm{GmbH}$.

\section{OPEN ACCESS}

This article is licensed under a Creative Commons Attribution 4.0 International License, which permits use, sharing, adaptation, distribution and reproduction in any medium or format, as long as you give appropriate credit to the original author(s) and the source, provide a link to the Creative Commons licence, and indicate if changes were made. The images or other third party material in this article are included in the article's Creative Commons licence, unless indicated otherwise in a credit line to the material. If material is not included in the article's Creative Commons licence and your intended use is not permitted by statutory regulation or exceeds the permitted use, you will need to obtain permission directly from the copyright holder. To view a copy of this licence, visit http://creativec ommons.org/licenses/by/4.0/.

\section{REFERENCES}

1. M. Oezel, T. Janitzky, P. Beiss, and C. Broeckmann: Wear, 2019, vols. $430-431$, pp. $272-79$.

2. A.L. Vasconcellos da Costa e Silva: J. Mater. Res. Technol., 2019, vol. 8 (2), pp. $2408-22$.
3. H. Fu, J.J. Rydel, A.M. Gola, F. Yu, K. Geng, C. Lau, H. Luo, and P.E.J. Rivera-Diaz-del-Castillo: Int. J. Fatigue, 2019, vol. 129.

4. F.J. Ebert: Chin. J. Aeronaut., 2019, vol. 23, pp. 123-36.

5. T.B. Lund: J. ASTM Int., 2010, vol. 7, pp. 81-96.

6. M.W.J. Lewis and B. Tomkins: Proc. Inst. Mech. Eng., Part J, 2012, vol. 226 (5), pp. 389-405.

7. Q.Y. Wang, C. Bathias, N. Kawagoishi, and Q. Chen: Int. J. Fatigue, 2002, vol. 24, pp. 1269-74.

8. K. Hashimoto, T. Fujimatsu, N. Tsunekage, K. Hiraoka, K. Kida, and E. Costa Santos: Mater. Des., 2011, vol. 32, pp. 4980-85.

9. K. Furumura, Y. Murakami, and T. Abe: Mot. Contr., 1996, vol. 1 , pp. $30-36$.

10. P.F.F. Walker: Mater. Sci. Technol., 2014, vol. 30, pp. 385-410.

11. K. Hashimoto, T. Fujimatsu, N. Tsunekage, K. Hiraoka, K. Kida, and E. Costa Santos: Mater. Des., 2011, vol. 32, pp. 1605-11.

12. G. Donzella, M. Faccoli, A. Mazzù, C. Petrogalli, and H. Desimone: Eng. Fract. Mech., 2011, vol. 78, pp. 2761-74.

13. W. Holzgruber and E. Plöckinger: Stahl Eisen., 1968, vol. 88, pp. 638-48.

14. W. Holzgruber and E. Plöckinger: Berg. Hüttenmänn. Monatsh., 1968, vol. 113, pp. 83-93.

15. E. Plöckinger: J. Iron Steel Inst., 1973, vol. 211, pp. 533-41.

16. A. Mitchell: J. Mater. Sci. Eng. A, 2005, vols. 413-414, pp. 10-18.

17. C.B. Shi, X.C. Chen, H.J. Guo, Z.J. Zhu, and H. Ren: Steel Res. Int., 2012, vol. 83, pp. 472-86.

18. Y. Liu, Z. Zhao, G. Li, Y. Wu, X. Wang, and B. Li: Metall. Res. Technol., 2019, vol. 116, pp. 1-9.

19. C. Shi and J.H. Park: Metall. Mater. Trans. B, 2019, vol. 50B, pp. $1139-47$.

20. C.K. Mills and B.J. Keene: Int. Met. Rev., 1981, vol. 1, pp. 21-69.

21. A. Mitchell: Ironmak. Steelmak., 1974, vol. 1, pp. 172-79.

22. A. Mitchell, F.-R. Carmona, and C.-H. Wei: Ironmak. Steelmak., 1982, vol. 11 , pp. $37-41$.

23. M. Allibert, J.F. Wadier, and A. Mitchell: Ironmak. Steelmak., 1978, vol. 5, pp. 211-16.

24. S. Radwitz, H. Scholz, B. Friedrich, and H. Franz: Proc. 2015 Int. Symp. Liq. Met. Process. Cast., 2015, N71.

25. H. Miska and M. Wahlster: Arch. Eisenhuettenwes., 1973, vol. 44, pp. $81-85$.

26. G. Reiter, W. Schuetzenhoefer, A. Tazreiter, C. Martinez, P. Wuerzinger, and C. Loecker: Proc. 2013 Int. Symp. Liq. Met. Process. Cast., 2013, pp. 213-18.

27. J.H. Liu, G.-X. Wang, Y.-P. Bao, Y. Yang, W. Yao, and X.-N. Cui: J. Iron Steel Res. Int., 2012, vol. 19, pp. 1-7.

28. R. Schneider, C. Schüller, P. Würzinger, G. Reiter, and C. Martinez: Berg. Hüttenmaenn. Monatsh., 2015, vol. 160, pp. 117-22.

29. Y.W. Dong, Z.-H. Jiang, Y.-L. Cao, A. Yu, and D. Hou: Metall. Mater. Trans. B, 2014, vol. 45B, pp. 1315-24.

30. R.S.E. Schneider, M. Molnar, S. Gelder, G. Reiter, and C. Martinez: Steel Res. Int., 2018.

31. A. Randak, A. Stanz, and W. Verderber: Stahl Eisen., 1972, vol. 92 , pp. 981-93.

32. G. Klösch, K. Huemer, A. Sormann, and G. Frank: Berg. Hüttenmänn. Monatsh., 2009, vol. 154, pp. 27-32.

33. R. Schneider, A. Paar, P. Zeller, G. Reiter, W. Schützenhöfer, and P. Würzinger: Berg. Hüttenmänn. Monatsh., 2011, vol. 156, pp. 112-18.

34. A. Mitchell: Can. Metall. Q., 1981, vol. 20, pp. 101-12.

35. H. Ohta and H. Suito: Metall. Mater. Trans. B, 1996, vol. 27B, pp. 943-53.

36. M.A.T. Andersson, P.G. Jönsson, and M.M. Nzotta: ISIJ Int., 1999, vol. 39, pp. 1140-49.

37. H. Miska and M. Wahlster: Arch. Eisenhuettenwes., 1973, vol. 44, pp. 19-25.

38. R. Schneider, M. Mülleder, P. Zeller, P. Würzinger, G. Reiter, and S. Paul: Proc. 2015 Int. Symp. Liq. Met. Process. Cast., 2015, N40.

39. E. Sjöqvist Persson and A. Mitchell: Proc. 2017 Int. Symp. Liq. Met. Process. Cast., 2017, pp. 373-79.

Publisher's Note Springer Nature remains neutral with regard to jurisdictional claims in published maps and institutional affiliations. 